\title{
MEMBACA AYAT-AYAT AL-QURAN DENGAN PERSPEKTIF IAN G. BARBOUR
}

\author{
Achmad Bisri \\ Fakultas Ushuluddin Universitas Islam Negeri (UIN) Walisongo Semarang \\ Jl. Prof. Dr. Hamka Km.1, Ngaliyan, Semarang \\ e-mail: achmadbisri@walisongo.ac.id
}

Asbtract: This aticle aims to understand the science verses of the Quran with Ian G. Barbour perspective. To elaborate the problem, I used the qualitative research with hermeneutic analysis. There are three findings important in the research. Firstly, regarding the relation between religion and science Ian G. Barbour divided four typologies: conflict, independence, integration, and dialogue. Secondly, regarding to the Quran verses in the line with Barbour's thought to be found that some possibilities the science explain the scientific verses of the Quran. Thirdly, with Barbour's perspective it was found the fact that relation the Qur'an and the science were conflict, independence, and integration.

Abstrak: Artikel ini bertujuan memahami ayat-ayat sains dengan perspektif Ian G. Barbour. Untuk menjelaskan masalah ini, saya menggunakan jenis penelitian kualitatif dengan analisis hermeneutik. Adapun temuan yang diperoleh dari penelitian ini adalah: Pertama, dalam mengemukan hubungan antara agama dan sains, Ian G. Barbour membagi ke dalam empat tipologi (konflik, independen, integrasi, dan dialog). Ia melihat bahwa keempat tipologi ini dijumpai di kalangan saintis dan agamawan. Kedua, Berkaitan dengan ayat-ayat al-Quran yang senada dengan pemikiran Ian G. Barbour memang ditemukan adanya kemungkinan sains menjelaskan ayat-ayat ilmiah dalam alQuran. Ketiga, dengan perspektif Ian G. Barbour, ditemukan fakta bahwa relasi al-Quran dan sains berada pada tipologi konflik, independen, dan integratif. Konflik terjadi ketika sains berbicara tentang alam yang terbebas dari campur tangan Tuhan; independensi terjadi ketika berkaitan dengan teori evolusi Darwin. Namun, integrasi terjadi juga ketika sains mampu memecahkan informasi-informasi ilmiah yang disajikan al-Quran.

Keywords: al-Quran, sains, dialog, integrasi, independen. 


\section{A. Pendahuluan}

Dalam Keputusan Rektor Institut Agama Islam Negeri (IAIN) Walisongo ${ }^{1}$ Semarang Nomor 10 Tahun 2014 disebutkan: "Perguruan Tinggi Islam Riset Terdepan Berbasis Kesatuan Ilmu Pengetahuan untuk Kemanusiaan dan Peradaban." Visi ini menyiratkan sebuah kesadaran bahwa ilmu pengetahuan tidak boleh lagi agama dikhotomis, agama di satu di sisi, dan sains (science) di sisi yang lain.

Visi ini sesungguhnya telah diisyaratkan oleh Rasulullah dalam banyak hadis yang menganjurkan pencarian ilmu ke mana saja ("Carilah ilmu walau ke negeri Cina") dan kapan saja ("Carilah ilmu dari buaian bayi hingga liang lahat"). Itulah sebabnya generasi awal, generasi-generasi ulama yang pertama rajin menerjemahkan karya-karya ilmiah dari berbagai bangsa dan bahasa untuk kemudian disesuaikan dengan ajaran Islam dan dikembangkan lebih lanjut. Jadi, secara instrinsik tidak ada pertentangan antara sains dan Islam. Sains dalam pengertiannya yang modern adalah pengembangan dari filsafat alam yang merupakan bagian dari filsafat yang menyeluruh dalam khazanah keilmuan Yunani. Namun, filsafat Yunani terlalu deduktif, yang lebih berdasarkan pada pemikiran spekulatif. Karena itu, perlu dilengkapi oleh pengamatan empiris sebagaimana yang diperintahkan oleh al-Quran. Dari sini, di tangan ilmuwan Muslim, sains

1Sejak 6 April 2015, IAIN sudah berubah status menjadi Universitas Islam Negeri (UIN) Walisongo dengan visi: "Universitas Islam Riset Terdepan Berbasis pada Kesatuan Ilmu Pengetahuan untuk Kemanusiaan dan Peradaban." berkembang dengan pesat. Pengujian ekperimentasi me- nenyebabkan sains Islam menjadi kukuh. Sains memperoleh karak-ternya yang rasional objektif selama gelombang pertama peradaban Islam. Namun, rasionalitas sains tak bisa dilepaskan dari rasionalitas religius karena teologi, filsafat, dan sains merupakan kesatuan integral. ${ }^{2}$

Kesadaran untuk mengintegrasikan agama dan sains ini secara internasional telah dibahas dalam "Konferensi Internasional Kajian Islam XIII-Integrasi Agama dan Sains ala Indonesia" di Lombok, Nusa Tenggara Barat, 18-21 Nopember 2013. Seorang pembicara dari Ibn Thufayl University, Maroko, Maryam Ait Ahmed mengatakan bahwa integrasi ilmu Islam dan ilmu lain sebenarnya sudah ada sejak jaman dahulu. Menurutnya, dalam sejarah ilmu peradaban Islam, para ulama juga mempelajari ilmu-ilmu orang lain yang disebut 'ilmu orangorang terdahulu' untuk mengakui warisan bersama umat manusia. Ia merujuk intelektual besar Islam seperti al-Kindī, Ibn Ṣinā, Ibn Rusyd, yang tidak pernah melontarkan klaim 'kedok-teran Islami' atau 'filsafat islami', namun hanya mengandalkan kajian ilmiahnya yang pada akhirnya memunculkan pengakuan bahwa buah pikir mereka adalah produk "orang Islam". "Maka kita tidak boleh memisahkan antara ilmu dīn dan ilmu dunia. Dengan demikian, integrasi keilmuan sangat perlu."3

${ }^{2}$ Armahedi Mahzar, Revolusi Integ-ralisme Islam: Merumuskan Paradigma Sains dan Teknologi Islami, Bandung: Mizan, 2004, h. 210211.

3"Konferensi Internasional Kajian Islam XIII - Integrasi Agama dan Sains ala Indonesia", 
Apa yang menjadi visi besar UIN Walisongo dan juga para ilmuwan Muslim di seluruh dunia tampaknya untuk menjawab hubungan yang tidak harmonis antara agama dan sains. ${ }^{4}$ Fenomena ini terlihat dari banyaknya seminar, terbitnya buku-buku dan munculnya artikel-artikel dengan tema tersebut. Tahun 1998, The Center for Theology and the Natural Science menyelenggarakan seminar dengan tema "Science and the Spiritual Quest", sehingga Newsweek menurunkan tajuk "Science Finds God". ${ }^{5}$ Jurnal Zygon, yang banyak memuat tulisan tentang isu agama dan sains, juga merupakan ikon penting dalam hal ini. Walaupun demikian, kajian sistematis tentang peta hubungan sains dan agama telah muncul sejak awal paruh kedua abad XX, dengan kehadiran Ian Barbour sebagai salah satu tokoh pentingnya. ${ }^{6}$

Ian G. barbour adalah seorang ilmuwan, ahli bidang fisika dan teologi, yang melalui beberapa bukunya, Nature, Human Nature, and God; Issues in Science and Religion, dan dalam terjemahan bahasa Indonesia, Juru Bicara Tuhan: Dialog antara Sains dan Agama (Bandung: Mizan, 2002), mencoba

diakses dari http://www.koran-
sindo.com/node/345974 (30 Januari 2014).

${ }^{4}$ Lihat misalnya beberapa tulisan yang membahas tentang hubungan tidak harmonis ini: Frederick Temple, The Relations between Religion and Science: Eight Lectures Preached before the University of Oxford in the Year 1884 on the Foundation of the Late Rev. John Bampton, M.A, Cambridge: Cambridge University Press, 2009; Willem B. Drees, Religion and Science in Context: A Guide to the Debates, London dan New York: Routledge, 2010.

${ }^{5}$ Ach. Maimun Syamsuddin, Integrasi Mutlidimensi Agama dan Sains: Analisis Sains Islam al-Attas dan Mehdi Golshani, Yogyakarta: IRCiSoD, 2012, h. 19.

IIbid., h. 19-20. menampilkan gambaran yang amat berbeda tentang sains dan agama. Melalui buku-bukunya itu, Barbous mengingatkan adanya "titik temu" antara sains dan agama, yang sebenarnya bisa saling melengkapi. Berangkat dari kerangka ini, maka Kitab Suci alQuran yang memuat informasiinformasi ilmiah (sains) akan dipahami dengan perspektif Barbour ini.

Sebagaimana diingatkan oleh Agus Purwanto ${ }^{7}$ bahwa al-Quran turun bukan di ruang hampa, juga bukan pada awal sejarah kelahiran umat manusia. AlQuran turun ketika beberapa peradaban telah berlangsung, beberapa pemikiran nonwahyu tentang alam telah berkembang. Artinya, sebelum al-Quran diturunkan, manusia telah mempunyai teori, pendapat, atau pandangan tentang aneka fenomena alam. Karena itu, ketika Islam datang dengan Kitab Suci alQurannya, bukan untuk menghapus paham-paham atau ajaran-ajaran yang pernah ada sebelumnya. Sebaliknya, Islam hadir untuk meluruskan yang menyimpang dan menyempurnakan yang kurang, termasuk tentang akal dan perannya dalam memahami alam fisik maupun nonfisik. Dengan kata-kata lain, sebagaimana dikatakan oleh Azyumardi Azra:

"Perubahan IAIN Syarif Hidayatullah Jakarta menjadi UIN Syarif Hidayatullah Jakarta pada dasarnya bertujuan untuk mendorong usaha reintegrasi epistemologi keilmuan yang pada gilirannya menghilangkan dikhotomi antara ilmu-ilmu agama

7Lihat: Agus Purwanto dalam dua bukunya: (1) Ayat-ayat Semesta: Sisi-sisi alQuran yang Terlupakan, Bandung: Mizan, 2013; dan (2) Nalar Ayat-ayat Semesta, Bandung: Mizan, 2012. 
dan ilmu-ilmu umum. Hal ini penting dalam rangka memberikan landasan moral Islam terhadap perkembangan iptek dan sekaligus mengartikulasikan ajaran Islam secara proporsional di dalam kehidupan masyarakat."8

Tulisan ini lebih jauh akan memfokuskan pada "membaca" Kitab Suci al-Quran yang berisi informasiinformasi dengan perspektif Ian G. Barbour tersebut. Barbour telah membagi empat tipologi relasi sains dan agama: konflik, independensi, integrasi, dan dialog.

\section{B. Tentang Ian G. Barbour}

Ian Graeme Barbour-selanjutnya digunakan Barbour-lahir pada 5 Oktober 1923 di Beijing, Republik Rakyat Tiongkok (Cina). Ia merupakan anak kedua dari tiga anak dari seorang ibu Episkopal Amerika dan seorang ayah Presbyterian Skotlandia. Ia menghabiskan masa kecilnya di Cina, Amerika Serikat, dan Inggris. Dia menerima gelar B.Sc. dalam fisika dari Universitas Swarthmore. Gelar M.Sc. dalam fisika dari Duke University pada tahun 1946, dan dan Ph.D. dalam fisika dari University of Chicago pada tahun 1950. Sedangkan gelar B.Div diraihnya pada tahun 1956 dari Universitas Yale's Divinity School. ${ }^{9}$

Barbour mengajar di Carleton College awal tahun 1955 sebagai Profesor agama. Pada 1970-an, ia mendirikan program Ilmu Pengetahuan, Teknologi, dan Kebijakan Publik (the

8Azyumardi Azra, "Sambutan Rektor," Prospektus UIN Syarif Hidayatullah Jakarta "Wawasan 2010" Leading Toward Research University, Jakarta: UIN Jakarta Press, 2006, h. ii. ur
Science, Technology, and Public Policy Program) di Carleton, yang kemudian menjadi program Studi Teknologi Lingkungan dan Teknologi (the Environment and Technology Studies program). Dia pensiun pada tahun 1986 sebagai Winifred dan Atherton Bean Profesor Emeritus Ilmu, Teknologi dan Masyarakat. ${ }^{10}$

Barbour menikah dengan Deane Kern dari tahun 1947 sampai kematiannya pada tahun 2011 Mereka memiliki empat anak. Ia menderita stroke pada 20 Desember 2013 di rumahnya di Northfield, Minnesota , dan tetap dalam keadaan koma di Rumah Sakit Abbott Northwestern sampai kematiannya empat hari kemudian (24 Desember 2013).

\section{B.1. Kiprah dan Karya-karya}

Sejarah hubungan ilmu dan agama di Barat mencacat bahwa pemimpin gereja menolak Teori Heliosentris Galileo atau Teori Evolusi Darwin. Pemimpin gereja membuat pernyataan yang berada di luar kompetensinya. Sementara di dunia Timur, dalam hal ini dunia Islam, pengajaran ilmu-ilmu agama Islam yang normatif-tekstual terlepas dari perkembangan ilmu pengetahuan dan teknologi, ilmu-ilmu sosial, ekonomi, hukum dan humaniora pada umumnya. ${ }^{11}$

Di Barat, wacana mengenai hubungan ilmu dan agama di era millenium baru ini dipopulerkan oleh Barbour. Teolog cum fisikawan Kristen ini dianggap sebagai salah seorang peletak

\footnotetext{
ur

${ }^{11}$ Waston, "Hubungan Sains dan Agama: Refleksi Filosofis atas Pemikiran Ian G. Barbour", PROFETIKA: Jurnal Studi Islam, Vol. 15, No. 1, Juni 2014, h. 77.
}

${ }^{10} \mathrm{http}: / /$ en.wikipedia.org/wiki/Ian_Barbo 
dasar wacana mutakhir sains dan agama, baik dari segi materi maupun metodologinya. Pengaruhnya kini telah amat menyebar berkat penerjemahan buku-bukunya, termasuk di Indonesia. ${ }^{12}$

Kiprah Barbour dalam konteks hubungan sains dan agama telah digambarkan secara komprehensif oleh Russel. Barbour dikenal sebagai salah seorang penggagas dialog antara sains dan agama sekarang ini. Ia telah mendedikasikan dirinya dan memberi kontribusi yang luas pada ranah ini. Kontribusinya dalam usaha menghubungkan antara sains dan agama dapat dikatakan jauh lebih besar daripada sumbangan para ahli lainnya bahkan sampai sekarang yang masih menulis. Sejak tulisan-tulisannya yang paling awal, Barbour telah memberi perhatian serius terhadap bentuk bagaimana hubungan yang tepat antara ilmu dan agama. Ia, karenanya secara terus menerus membahas masalah ini.

Pengakuan atas otoritasnya dalam perbincangan sains dan agama datang dalam bentuk undangan untuk memberikan rangkaian kuliah Gifford Lectures pada 1989-1991. Forum akademik yang prestisius ini bertujuan "mempromosikan studi mengenai Theology of Nature dalam makna terluasnya, yaitu ilmu mengenai Tuhan. Dari ceramah-ceramah ini, ia menerbitkan buku terpentingnya, Religion in an Age of Science and Ethics in an Age of Technology.

Mengenai peran Barbour dalam perkembangan terakhir ini, para peng-

${ }^{12}$ Zaenal Abidin Bagir, "Pengantar" dalam Ian G. Barbour, Juru Bicara Tuhan, Antara Sans dan Agama, terj. E.R. Muhammad, Bandung: Mizan, 2002, h. 22. kaji sains dan agama sepakat, tak berlebihan mengatakan bahwa dialah peletak dasar wacana mutakhir tentang sains dan agama. Tentu, dia bukan orang pertama yang menaruh perhatian pada isu yang sudah berusia lama ini. Sejak awal perkembangan sains modern, pertanyaan-pertanyaan menyangkut otoritas teori sains dan otoritas wahyu sudah kerap muncul. Lalu pada awal abad ke 20, kita sering menemui lontaranlontaran religius para ilmuwan besar, seperti Einstein, Heisenberg atau Planck dan lain-lain. Akan tetapi, sebagaimana diakui para pengkaji isu ini, Barbour adalah orang pertama yang secara amat serius mengembangkan wacana ini, baik dari segi materi maupun metodologinya. ${ }^{13}$

Dalam jurnal Zygon, yang berspesialisasi pada sains agama, Gregory R. Peterson bahkan mencatat dasawarsa 1990 sebagai titik balik penting dalam lanskap wacana sains dan agama. Pada awal dasawarsa itu, aecara serentak terbit beberapa buku akademik pada saat yang hampir bersamaan (di antaranya buku Barbour, Religion in an Age of science). Salah satu pengakuan penting akan keberhasilan rintisannya ini terwujud dalam pemberian penghargaan Templeton (yang besarnya satu juta dolar AS, lebih besar daripada hadiah Nobel) pada tahun 1999. Dalam kesempatan itu, Barbour mendapat pujian dari John B. Cobb:

"No contemporary has made a more original, deep and lasting contribution toward the needed integration of

${ }^{13}$ Zubaidi, Dialog antara Sains menurut Ian G. Barbour dengan Ayat-ayat al-Qur'an, Skripsi pada Fakultas Ushuluddin IAIN Walisongo Semarang, 2005, h. 14. 
scientific and religious knowledge and values than Ian Barbour. With respect to the breadth of topics and fields brought into this integration, Barbour has no equal." 14

"Tidak ada yang hasilkan di era kontemporer ini suatu yang lebih orisinal, kontribusi mendalam dan abadi terhadap kebutuhan integrasi ilmiah dan nilai-nilai dan pengetahuan agama daripada Barbour. Sehubungan dengan luasnya topik dan bidang dibawa ke integrasi ini, Barbour tidak ada bandingannya."

Seluruh hadiah itu, dia sumbangkan ke Center for Theology and Natural Sciences, yang setahun sebelumnya menjadi penyelenggara SSQ di Berkeley. Dia mengatakan "tujuan saya sejak awal terlibat dalam wacana ini adalah mempromosikan dialog tentang masalahmasalah konseptual dan etis, bukan mencampuradukkan sains dan agama. Dari pandangan yang meletakkan sains dan agama dalam kotak-kotak terpisah, saya bergerak untuk menemukan wilayah-wilayah subur bagi pengembangan interaksi keduanya."

\section{B.2. Karya-karyanya}

Hampir semua buku Barbour bertujuan utama untuk memberikan peta bagi para ahli yang sejalan dengan pemikirannya.

Dalam usahanya untuk menghubungkan ilmu pengetahuan dan agama di Isu dalam Sains dan Agama, Barbour menciptakan istilah 'realisme kritis'. Ini telah diadopsi oleh para sarjana lainnya. Ia mengaku struktur dasar agama adalah sama dengan ilmu pengetahuan dalam beberapa hal tetapi juga berbeda pada beberapa poin penting. Mereka adalah bagian dari spektrum yang sama di mana kedua layar 'subjektif' serta fitur 'obyektif'. Subjektif meliputi teori pada data, ketahanan teori komprehensif untuk pemalsuan, dan tidak adanya aturan untuk pilihan antara paradigma. Fitur tujuan termasuk adanya data umum, bukti untuk atau terhadap teori, dan kriteria yang tidak tergantung paradigma. Kehadiran fitur subjektif dan objektif dalam ilmu pengetahuan dan agama membuat nya berpikir berharga dan asli. Argumen Barbour telah dikembangkan secara signifikan dan beragam oleh berbagai sarjana, termasuk Arthur Peacocke, John Polkinghorne, Sallie McFague dan Robert John Russell.

Karya-karya penting Barbour adalah: Issues in Science and Religion (New York: Harper \& Row Publisher, 1971), When Science Meets Religion (New York: Harper Sanfrancisco, 2000), Menemukan Tuhan dalam Sains Kontemporer dan Agama (Bandung: Mizan, 2005).

\section{Ayat-Ayat Sains Perspektif Ian G. Barbour}

Muhammad Quraish Shihab pernah mengingatkan bahwa al-Quran bukan suatu kitab ilmiah sebagaimana halnya kitab-kitab ilmiah yang dikenal selama ini. Salah hal yang membuktikan kebenaran pernyataan di atas adalah sikap al-Quran terhadap pertanyaan yang diajukan oleh para sahabat Nabi tentang kejadian bulan: "Mereka bertanya kepadamu tentang bulan" (QS. al-Baqarah [2]: 189). Menurut ayat ini, mereka bertanya mengapa bulan (sabit) 
terlihat dari malam ke malam membesar hingga purnama, kemudian sedikit demi sedikit mengecil, hingga menghilang dari pandangan mata. ${ }^{15}$

Pertanyaan di atas, lanjut Shihab, tidak dijawab al-Quran dengan jawaban ilmiah yang dikenal oleh astronom, tetapi jawabannya justru diarahkan kepada upaya memahami hikmah di balik kenyataan itu, ${ }^{16}$ untuk menunjukkan kebesaran Tuhan dan keesaan-Nya serta mendorong manusia seluruhnya untuk mengadakan observasi dan penelitian demi lebih menguatkan iman dan kepercayaan kepada-Nya. ${ }^{17}$ Di sini alQuran tetap memberikan kesempatan kepada mereka yang mempunyai nalar (akal) untuk memecahkan pertanyaanpertanyaan yang diajukannya.

Al-Quran menyebut akal ('aql) sebanyak 49 kali dengan 48 kata dalam bentuk kata kerja sedang/akan atau imperfektum (fi'il muḍāri') dan satu kata kerja lampau (f'il māḍi). tepatnya, ya'qilūn 22 kali, ta'qilūn 24 kali, dan na'qilu, ya'qilu, 'aqalū, masing-masing satu kali. Masing-masing pola mempunyai karakteristik pesan tersendiri. ${ }^{18}$ Dengan mencermati posisi akal ini, maka Allah menghendaki agar manusia yang mau menggunakan akal-nya tersebut untuk merenungi dan memecahkan misteri-misteri alam semesta

\footnotetext{
${ }^{15}$ M. Quraish Shihab, Mukjizat al-Quran ditinjau dari Aspek Kebahasaan, Isyarat Ilmiah, dan Pemberitaan Gaib, Bandung: Mizan, 1997.

${ }^{16}$ Ibid., h. 166.

${ }^{17}$ M. Quraish Shihab, "Membumikan" alQuran: Fungsi dan Peran Wahyu dalam Kehidupan Masyarakat, Bandung: Mizan, 1996, h. 51.

${ }^{18}$ Agus Purwanto, Nalar Ayat-ayat Semesta: Menjadikan al-Quran sebagai Basis Konstruksi Ilmu Pengetahuan, Bandung: Mizan, 2012, h. 59.
}

yang diciptakan-Nya. Inilah yang disebut dengan ayat-ayat kauniyah, yang di dalamnya berisi informasi-informasi ilmiah (sains).

Dalam tulisan ini, penulis hanya membatasi ayat-ayat sains yang menjadi konsen Ian G. Barbour dalam bukunya yang membahas dua persoalan pokok, yakni (1) kejadian alam semesta, dan (2) evolusi dan penciptaan manusia. ${ }^{19}$ Kedua persoalan ini, masing-masing dibahas di bawah ini.

\section{C.1. Kejadian Alam Semesta}

Dalam al-Quran dijumpai beberapa ayat yang membahas tentang kejadian alam semesta sebagai berikut:

Dan kamu lihat gunung-gunung itu, kamu sangka ia tetap di tempatnya, padahal ia berjalan sebagai jalannya awan. (Begitulah) perbuatan Allah yang membuat dengan kokoh tiaptiap sesuatu; sesungguhnya Allah Maha mengetahui apa yang kamu kerjakan (QS. al-Naml [27]: 88).

Tuhan yang memelihara kedua tempat terbit matahari dan Tuhan yang memelihara kedua tempat terbenamnya (QS. al-Rahman [55]: 17).

Sesungguhnya Kami telah mengutus Rasul-rasul Kami dengan membawa bukti-bukti yang nyata dan telah Kami turunkan bersama mereka Al-Kitab dan neraca (keadilan) supaya manusia dapat melaksanakan keadilan. Dan Kami ciptakan besi yang padanya terdapat kekuatan yang hebat dan berbagai manfaat bagi manusia, (supaya mereka mempergunakan besi itu) dan supaya Allah mengetahui siapa yang menolong (agama)-Nya dan rasul-rasul-Nya,

${ }^{19}$ Ian G. Barbour, Menemukan Tuhan dalam Sains Kontemporer dan Agama, terj. Fransiskus Borgias M, Bandung: Mizan, 2005. 
padahal Allah tidak dilihatnya. Sesungguhnya Allah Maha kuat lagi Maha Perkasa (QS. al-Hadid [57]: 25)

Maha suci Allah, yang telah memperjalankan hamba-Nya pada suatu malam dari Al-Masjidil Haram ke AlMasjidil Aqsha yang telah Kami berkahi sekelilingnya agar Kami perlihatkan kepadanya sebagian dari tanda-tanda (kebesaran) Kami. Sesungguhnya Dia adalah Maha mendengar lagi Maha mengetahui (QS. al-Isra [17]: 1).

Allah Pencipta langit dan bumi, dan bila Dia berkehendak (untuk menciptakan) sesuatu, maka (cukuplah) Dia hanya mengatakan kepadanya: "Jadilah!" lalu jadilah ia (QS. alBaqarah [2]: 117).

Dan Dialah yang menciptakan langit dan bumi dengan benar; dan benarlah perkataan-Nya di waktu Dia mengatakan: "Jadilah, lalu terjadilah", dan di tangan-Nyalah segala kekuasaan di waktu sangkakala ditiup. Dia mengetahui yang ghaib dan yang nampak. dan Dialah yang Maha Bijaksana lagi Maha mengetahui (QS. al-An'am [6]: 73).

Dari ayat di atas, Tuhan memberitahukan kepada kita bagaimana Dia menciptakan langit dan bumi ini dengan hanya mengatakan "kun fayakūn", yang tampak seperti "mirip permainan sulap yang diawali dengan mantra Sim Salabim atau Abrakadabra". Di sini memang sangat sulit dinalar oleh akal manusia, karena tidak melalui proses yang masuk akal, dan sebab akibat bagi proses penciptaannya. Namun, menurut Agus Purwanto, dalam penciptaan dan penyelenggaraan tatanan alam semesta, Tuhan menyertakan edukasi bagi manusia. Tidak ada kesulitan atau halangan bagi-Nya untuk men- ciptakan dan menyelenggarakan sendiri segala sesuatu yang di langit dan di bumi. ${ }^{20}$

Sementara itu, menurut mufassir M. Quraish Shihab, kata "kun" dalam firman-Nya "kun fayakūn" digunakan untuk menggambarkan betapa mudah bagi Allah menciptakan sesuatu dan betapa cepat terciptanya sesuatu itu bila Dia menghendaki. Cepat dan mudahnya diibaratkan dengan mengucapkan kata kun, walaupun sebenarnya Allah tidak perlu mengucapkannya, karena Dia tidak memerlukan suatu apa pun untuk mewujudkan apa yang dikehendaki-Nya.

"Sekali lagi, kata kun hanya untuk melukiskan-buat manusia-be-tapa Allah tidak membutuhkan sesuatu untuk mewujudkan kehendak-Nya dan betapa cepat sesuatu dapat wujud, sama bahkan lebih cepat-jika Dia meng-hendaki-dari masa yang diguna-kan manusia mengucapkan kata kun."21

Dari penjelasan di atas jelaslah bahwa Tuhanlah Pencipta awal, Pengatur, Pemelihara, dan Penghancur alam semesta ini sesuai dengan kehendak-Nya. Ini, misalnya, dijelaskan dalam ayat pertama surah al-Fatihah: "al-Hamdu li Allāh Rabb al-'Ālamīn" (segala puji bagi Allah Rabb semesta alam). Menurut Maulana Muhammad Ali, dalam kata Rabb itu terkandung makna yang lengkap sebagai berikut:

Hence Rabb is the Author of all existence, Who has not only given to the whole creation its means of nourishment but has also beforehand ordained for each a sphere of capacity

\footnotetext{
${ }^{20}$ Agus Purwanto, Nalar Ayat-ayat Semesta, h. 319.

${ }^{21}$ M. Quraish Shihab, Tafsir al-Mishbāh: Pesan, Kesan dan Keserasian al-Qur'an, Vol. IV, Jakarta: Lentera Hati, 2001, h. 153.
} 
and within that sphere provided the means by which it continues to attain gradually to its goal of perfection. By the use of the word Rabb the Holy Qur'an thus hints at the law of evolution which is working in the universe."22

"Jadi, Rabb ialah Pencipta sekalian makhluk, Yang bukan hanya memberi penghidupan saja, melainkan bagi tiap-tiap makhluk telah Ia tentukan sebelumnya daya kemampuan, dan dalam lingkungan daya kemampuan itu telah Ia siapkan sarana, yang dengan sarana itu mereka secara berangsur-angsur dapat meneruskan perkembangannya hingga mencapai puncak kesempurnaan. Jadi dengan dicantumkannya sifat $R a b b$, al-Quran mengisyaratkan adanya hukum evolusi yang bekerja di alam semesta."

Lalu bagaimana pendapat para saintis? Dalam catatan Barbour, para saintis terbelah: ada yang tetap mengakui keterlibatan Tuhan da nada yang menolak campur tangan Tuhan dalam penciptaan alam semesta ini. ${ }^{23}$

Bagi yang menolak campur tangan Tuhan, mereka sama sekali tidak menempatkan Tuhan untuk mengisi celah-celah yang belum dijelaskan dalam uraian ilmiah. Inilah kaum ateis. Kaum ini mengatakan bahwa materi berasal dari keabadian, bahwa ia tidak memiliki permulaan, dan bahwa semua bentuk berkembang secara kebetulan. Sebagai contoh, seorang pakar teori materialis ternama George Politzer,

\footnotetext{
${ }^{22}$ Maulana Muhammad Ali, The Holy Qur'an: Arabic Text, English Translation, and Commentary, Lahore, Inc. U.S.A.: Ahmadiyah Anjuman Isha'at Islam, 1991, h. 3.

${ }^{23}$ Ian G. Barbour, Menemukan Tuhan, h. 77.
}

dalam tulisannya, menyatakan bahwa alam semesta tidak diciptakan; kalau memang diciptakan, maka semesra itu pastilah buah karya Tuhan yang menciptakannya pada suatu masa dari ketiadaan. Oleh karena itu, agar bisa menerima teori penciptaan, kita harus membayangkan adanya suatu masa saat tidak ada alam semesta, karena ia muncul dari kehampaan. ${ }^{24}$

Sementara yang menerima campur tangan Tuhan menegaskan bahwa adanya bukti sains yang mendukung keterlibatan Tuhan dalam penciptaan.

“...Allah mempunyai satu peranan yang berkelanjutan dalam menopang dunia dan hukum-hukumnya...dunia ini tidak berdiri sendiri, tetapi membutuhkan dukungan terusmenerus dari Allah agar bisa bertahan dan kuat."25

Barbour termasuk yang menerima adanya campur tangan Tuhan dalam penciptaan alam semesta ini. "Allah melampaui alam, tetapi Dia imanen dalam proses-proses temporal, karena Allah hadir dalam proses terwujudnya setiap peristiwa. Ini berarti, alam tidak boleh dieksploitasi atau disembah, tetapi harus dihormati dan dihargai, karena alam adalah panggung bagi aktivitas Allah yang terus berkelanjutan," tegas Barbour. ${ }^{26}$ Di bagian lain, alQuran menyatakan bahwa Allah menciptakan tatasurya ini selama enam hari:

Allahlah yang menciptakan langit dan bumi dan apa yang ada di antara keduanya dalam enam masa,

${ }^{24}$ Caner Taslaman, Miracle of the Quran: Keajaiban al-Quran Mengungkap Penemuanpenemuan Ilmiah Modern, Bandung: Mizan, 2010, h. 45.

${ }^{25}$ Ibid., h. 80.

${ }^{26}$ Ibid., h. 286. 
kemudian Dia bersemayam di atas 'Arsy (QS. as-Sajdah [32]: 4).

Merujuk QS. al-Hajj [22]: 47 dijelaskan bahwa satu hari itu setara dengan 1.000 tahun Qamariyah (lunar year) atau 972 tahun Syamsiah (solar year), yakni tahun pergantian musim. Dengan demikian, yang dimaksud enam hari pada ayat di atas adalah 6.000 tahun. ${ }^{27}$ Lalu ditegaskan bahwa Dia bersemayam di 'Arsy, yang berarti Allah menciptakan dunia seperti yang kita lihat ini dalam enam jarak waktu yang besar, tetapi setelah penciptaan pertama, Dia masih berkuasa, mengatur, dan mengawasi segala masalah. Dia tidak menyerahkan kekuasaan-Nya kepada yang lain, lalu Dia sendiri beristirahat. $^{28}$ Dia tetap mengurus ciptaan-Nya tanpa terikat oleh waktu, dan tidak pernah beristirahat sejenak pun:

Allah, tidak ada Tuhan (yang berhak disembah) melainkan Dia yang hidup kekal lagi terus menerus mengurus (makhluk-Nya); tidak mengantuk dan tidak tidur. Kepunyaan-Nya apa yang di langit dan di bumi. Tiada yang dapat memberi syafa'at di sisi Allah tanpa izin-Nya? Allah mengetahui apa-apa yang di hadapan mereka dan di belakang mereka, dan mereka tidak mengetahui apa-apa dari ilmu Allah melainkan apa yang dikehendaki-Nya. Kursi Allah meliputi langit dan bumi. dan Allah tidak merasa berat memelihara keduanya, dan Allah

${ }^{27}$ Nazwar Syamsu, al-Qur'an Dasar Tanya Jawab Ilmiah, Jakarta: Ghalia Indonesia, t.th, h. 20.

${ }^{28}$ Abdullah Yusuf Ali, Qur'an: Terjemahan dan Tafsirnya, terj. Ali Audah, Jakarta: Pustaka Firdaus, 1994, h. 1065.
Maha Tinggi lagi Maha besar (QS. alBaqarah [2]: 255).

Sekiranya ada di langit dan di bumi tuhan-tuhan selain Allah, tentulah keduanya itu telah rusak binasa. Maka Maha suci Allah yang mempunyai 'Arsy dari apa yang mereka sifatkan. Dia tidak ditanya tentang apa yang diperbuat-Nya dan merekalah yang akan ditanyai. Apakah mereka mengambil tuhan-tuhan selain-Nya? Katakanlah: "Tunjukkanlah hujjahmu! (al-Quran) ini adalah peringatan bagi orang-orang yang bersamaku, dan peringatan bagi orang-orang yang sebelumku." Sebenarnya kebanyakan mereka tiada mengetahui yang hak, karena itu mereka berpaling; dan Kami tidak mengutus seorang Rasulpun sebelum kamu melainkan Kami wahyukan kepadanya: "Bahwasanya tidak ada Tuhan (yang hak) melainkan Aku, maka sembahlah olehmu sekalian akan Aku". (QS. alAnbiya [21]: 22-25).

Dengan demikian, Allah sendiri yang menciptakan alam semesta, manusia dan segala yang melata di atas bumi serta yang terkandung di dalamnya. Allah telah menjadikan semua itu dari tidak ada dan meletakkannya dalam suatu sistem yang indah lagi rapi agar dapat menjadikan sasaran pemikiran akal, sehigga darinya dapat disimpulkan adanya Pencipta Yang Maha Esa secara pasti, dan juga agar kehidupan manusia di dalamnya menjadi mudah dan gampang. ${ }^{29}$

Untuk menjelaskan secara ilmiah tentang asal mula alam semesta ini secara ilmiah, penulis akan mengutip secara panjang lebar teori Big Bang yang

${ }^{29}$ M. Yusuf Musa, Al-Quran dan Filsafat, Jakarta: Bulan Bintang, 1988, h. 11. 
dikutip dari Caner Taslaman sebagai berikut:

Teori Big Bang membenarkan bahwa alam semesta dan waktu memiliki permulaan dan materi tidak berasal dari keabadian, tetapi diciptakan. Pernyataan bahwa alam semesta muncul dari keabadian sudah dipatahkan. Big Bang tidak hanya menunjukkan alam semesta diciptakan oleh Sang Maha Pencipta, tetapi secara bersamaan juga membuktikan kelirunya keyakinan semisal pendistribusian kekuasaan di antara dewa-dewa, masing-masing menguasai bumi, matahari, bulan, dan gunung. Jelaslah bahwa siapa pun Dia, Dialah yang merancang komposisi awal dari alam semesta, yang menyebabkan terjadinya Big Bang, Pencipta segala sesuatunya. Dengan demikian, alam semesta berada di bawah kendali eksklusif Satu Penguasa Tunggal dan kekuasaan ini tidak dibagi. Jagat raya ini muncul dari satu titik tunggal; Pencipta titik itu adalah juga Pencipta manusia, sungai, bintang, kupu-kupu, supernova, warna, penderitaan dan kebahagiaan, musik dan estetika. Karena segalanya maujud muncul dari keesaan, Dia pastilah Pencipta "keesaan" itu.

Big Bang menunjukkan bahwa materi yang dipuja kaum ateis, dan materi yang menyusun keseluruh-an alam semesta ini tidak lain adalah sebutir debu yang tak berarti, bisa dikatakan demikian. Mereka yang menyaksikan bahwa dari butiran tak berarti telah muncul manusia, binatang buas, tanaman, dan jagat raya dalam cahayanya yang berkilauan, memahami bahwa kegeniusan itu tidak termaktub di dalam materi itu sendiri, tetapi sesuatu di luarnya, yaitu Sang Pencipta. Tutup mata Anda dan cobalah membayangkan keham-paan, lalu buka mata Anda dan lihat pepohonan, lautan, langit, bayangan Anda sendiri yang terpantul di cermin, makanan yang tersaji untuk Anda santap, dan karya seni....Bagaimana mungkin semua kemegahan ini muncul sendiri dari kegelapan dan dari satu titik tunggal dalam kehampaan? Bagi otak yang cerdas, ciptaan itu terungkap tidak hanya dalam estetika seni, tetapi juga dalam kerangka matematis. Kecepatan pengembangan alam semesta berada pada besaran yang sangat kritis. Menurut ungkapan seorang ilmuwan, andai saja kecepatan ledakan purba lebih lambat 1/1018-nya, maka alam semesta akan runtuh, tenggelam ke dalam dirinya sendiri dan tidak mungkin menjadi seperti sekarang ini. Demikian pula halnya dengan kuantitas materi, jika ia kurang dari yang sebenarnya, alam semesta tidak akan tersebar ke sekitar, membuat pembentukan benda-henda langit menjadi tak mungkin. Kekuatan yang berlaku dalam pemecahan komposisi awal pada saat penciptaan tidak hanya hebat tiada bandingan, tetapi rancangan di baliknya luar biasa brilian. Segala sesuatunya di-rancang oleh Sang Pencipta untuk memungkinkan keberadaan alam semesta. Semua peristiwa ini adalah sarana untuk menunjukkan kekuasaan tak terbatas Sang Pencipta kepada orang-orang yang matanya tertutup itu. Untuk menunjukkan fakta bahwa Dia merancang segala sesuatunya sampai detail sekecilkecilnya dengan sempurna. Kita menyaksikan fakta lain lewat fenomena ini: tidak ada "tak mungkin" dalam kosakata Sang Pencipta; jika 
Dia berkehendak agar sesuatu tercipta, maka terciptalah. 30

Dari uraian di atas dapatlah digarisbawahi bahwa alam semesta ini diciptakan oleh Allah, dan Dia akan memelihara ciptaan-Nya, dan akan menghancurkannya sesuai dengan kehendak-Nya.

\section{C.2. Evolusi dan Penciptaan \\ Manusia}

Ian G. Barbour mengambil tokoh evolusi, Charles Darwin. Menurut Barbour, teori evolusi yang dikemukakan Darwin menghebohkan pandangan tradisional. Sejak saat itu, banyak disiplin ilmiah mengumpul-kan berbagai bukti akan kenyataan bahwa manusia merupakan keturunan leluhur pramanusia. Dari biologi molukuler dewasa ini, kita mengetahui bahwa simpanse dan manusia memiliki lebih 99 persen DNA yang sama, walaupun tentu saja satu persen yang berbeda itu sangatlah penting. Para antropolog di Afrika menemukan pelbagai macam bentuk fosil peralihan antara simpanse dan manusia. Apa yang disebut Australopithecus afarensis, yaitu makhluk yang mirip kera, setelah berjalan dengan dua tungkai kira-kira 4 juta tahunn yang lalu. Di Etiopia, sudah ditemukan tulangbelulang dari makhluk yang dinamai Lucy, makhluk betina makhluk ini sudah berjalan dengan kedua tungkainya, mempunyai lengan yang panjang dan ukuran tengkorak yang sama dengan kera besar, sementara giginya memperlihatkan ia sebagai pemakan daging. Tampaknya perpindahan dari pepohonan ke padang rumput menyebabkan terjadinya perubahan ke arah postur 48-49. tubuh yang tegap, yang memungkinkan adanya kebebasan yang lebih besar untuk memanipulasi objek-objek, jauh lebih banyak mengandalkan penglihatan, dan beralih ke kegiatan berburu; hal itu terjadi jauh sebelum perkembangan otak yang lebih besar. Homo erectus, dua juta tahun yang silam, sudah mempunyai otak yang jauh lebih besar, mereka hidup dalam situs kelompok yang bertahan lama, membuat alat-alat yang jauh lebih rumit, dan mungkin juga mereka sudah memakai api. ${ }^{31}$

Bentuk-bentuk purba Homo sapiens muncul 400.000 tahun yang silam, dan kelompok Neanderthal sudah ada di Eropa150.000 tahun yang silam, walaupun mereka mungkin saja tidak ada dalam satu garis keturunan dengan manusia modern. Kelompok Cromagnon membuat lukisan di dinding gua dan melakukan upacara penguburan kirakira 30.000 tahun yang silam. Tulisan yang diketahui paling awal, yaitu tulisan orang Sumeria, sudah berusia 6.000 tahun. Pelbagai teknik pembuatan biji besi metalik akhirnya melahirkan Zaman Perunggu dan kemudian, kurang dari 3.000 tahun yang silam, muncullah Zaman Besi. Setidak-tidaknya di sini kita mempunyai garis besar perkembang-an evolusi, baik dari fisiologi maupun perilaku, dari pelbagai bentuk kehidupan nonhuman hingga bentuk human dan permulaan kebudayaan manusia. ${ }^{32}$ Lalu bagaimana tanggapan al-Quran tentang evolusi ini?

Menurut Quraish Shihab, di kalangan ilmuwan Muslim ada juga yang membenarkan teori Darwin tersebut.

${ }^{31}$ Ian G. Barbour, Menemukan Tuhan, h. 105-106.

${ }^{32}$ Ibid., h. 106. 
Ilmuwan Muslim ini memperkuat argumen mereka dengan ayat: "mengapakah kamu sekalian tidak memikirkan/memper-cayai kebesaran Allah, sedangkan Dia telah menjadikan kamu berfase-fase" (QS. Nuh [71]: 1314). Fase-fase ini menurut mereka sesuai dengan teori Darwin dalam proses kejadian manusia. Sedangkan ayat "adapun buih maka akan lenyaplah ia sebagai sesuatu yang tak bernilai, sedangkan yang berguna bagi manusia tetap tinggal di permukaan bumi" (QS. ar-Ra'd [13]:17) dijadikan bukti kebenaran teori "struggle for life" yang menjadi salah satu landasan teori Darwin. ${ }^{33}$

Menurut Quraish Shihab, ayat-ayat yang dijadikan penguatan teori Darwin tidak dapat dijadikan dasar untuk menguatkan dan membenar-kan teori tersebut, tetapi ini bukan berarti bahwa teori tersebut salah menurut al-Quran. Shihab mengutip pendapat 'Abbas al'Aqad yang menerangkan dalam bukunya al-Falsafah al-Qur'aniyah, sebagai berikut:

"Mereka yang mengingkari teori evolusi dapat mengingkarinya dari diri mereka sendiri, karena mereka tidak puas terhadap kebenaran argumentasi-argumentasinya. Tetapi mereka tidak boleh mengingkarinya berdasarkan al-Quran al-Karim, karena mereka tidak dapat menafsirkan kejadian asal-usul manusia dari tanah dalam satu penafsiran saja kemudian menyalahkan penafsir-an-penafsiran lainnya." 34

${ }^{33}$ M. Quraish Shihab, "Membumikan" alQuran, h. 48.

${ }^{34}$ Ibid., h. 49.
Hal senada dinyatakan pula oleh Muhammad Rasyīd Rị̣a dalam majalah al-Manar:

"Teori Darwin tidak membatal-kanbila teori tersebut benar dan merupakan hal yang nyata-tentang satu dasar dari dasar-dasar Islam; tidak bertentangan dengan satu ayat dai ayat-ayat al-Quran. Saya mengenal dokter-dokter dan lainnya yang sependapat dengan Darwin. Mereka itu orang-orang mukmin dengan keimanan yang benar dan Muslim dengan keislaman sejati; mereka menunaikan sembahyang dan kewajiban-kewajiban lainnya, meninggalkan keonaran, dosa dan kekejaman yang dilarang Allah sesuai dengan ajaran-ajaran agama mereka. Tetapi teori tersebut adalah ilmiah, bukan persoalan agama sedikit pun." 35

Setelah memaparkan pendapat para ahli Islam tersebut, Quraish Shihab menegaskan bahwa kita tidak dapat membenarkan atau menyalah-kan teoriteori ilmiah dengan ayat-ayat al-Quran; setiap ditemukan suatu teori cepatcepat pula kita membuka lembaranlembaran al-Quran untuk membenarkan atau menyalahkannya, karena apabila teori yan dibenarkan itu ternyata salah atau sebaliknya, maka musuh-musuh Islam mendapat kesempatan yang sangat baik untuk menyalahkan Kitab Allah sambil mencemooh kaum Muslim. Jalan yang lebih tepat guna membantah cemoohan ialah dengan menghindarkan sebab-sebab ce-moohan itu, ${ }^{36}$ sebagaimana ditegas-kan dalam alQuran:

\footnotetext{
${ }^{35}$ Ibid., h. 49.

${ }^{36}$ Ibid., h. 49.
} 
Janganlah kamu mencerca orangorang yang menyembah selain Allah, karena hal ini menjadikan mereka mencerca Allah dengan melampaui batas, karena kebodohan mereka (QS. al-An'am [6]: 108)."

Bertitik tolak dari penjelasan di atas, maka langkah selanjutnya adalah menelusuri penjelasan al-Quran mengenai asal-usul manusia. Misalnya, alQuran menjelaskan bahwa manusia diciptakan dari debu dan air. Terkadang al-Quran menekankan elemen-elemen ini secara terpisah, terkadang secara bersamaan.

Dan sesungguhnya Kami telah menciptakan manusia dari suatu saripati (berasal) dari tanah (QS. alMu'minūn [23]: 12).

Yang membuat segala sesuatu yang Dia ciptakan sebaik-baiknya dan yang memulai penciptaan manusia dari tanah. (QS. al-Sajdah [32]: 7).

Dan di antara tanda-tanda kekuasaanNya ialah Dia menciptakan kamu dari tanah, kemudian tiba-tiba kamu (menjadi) manusia yang berkembang biak (QS. al-Rūm [30]: 20).

Sebelum ilmu pengetahuan berkembang seperti sekarang, tak terhitung banyaknya spekulasi mengenai penciptaan manusia dari tanah liat (kombinasi debu dan air). Setelah berkembangnya ilmu biologi dan kimia, penelitian analitik terhadap tanah liat dan tubuh manusia dilakukan. Hasilnya menunjukkan bahwa zat-zat penyusun tanah liat dan penyusun manusia tepat sama. Zat-zat tersebut adalah zat besi, kalsium, oksigen, natrium, kalium, magnesium, hidrogen, klorin, yodium, mangan, timah, fosfor, karbon, seng, sulfur, dan nitrogen. ${ }^{37}$

\section{C.3. Saripati Tanah Liat}

Seperti telah dijelaskan dalam Surah al-Mu'minun ayat 12 , manusia diciptakan dari suatu saripati. Tuhan menggabungkan unsur-unsur yang terkandung dalam tanah liat dengan perhitungan tepat. Unsur-unsur ini secara harmonis dan proporsional tersebar dalam tubuh kita saat kita dilahirkan; tubuh diprogram untuk mempergunakannya dengan jumlah yang telah ditentukan dan membuang kelebihannya.

Tubuh manusia me-ngandung kalsium kira-kira sebanyak 2 kg. Jika jumlah ini berkurang, menggigit apel saja akan mengakibatkan gigi pecah. Tubuh kita membutuhkan 120 gram kalium. Ke-kurangan kalium dapat menga-kibatkan kejang otot, kelelahan, gangguan pencernaan, dan gemetar. Kita hanya membutuhkan seng sebanyak 23gram. Sedikit saja kurang dari jumlah yang dibutuhkan dapat mengakibatkan kehilangan daya ingat, impotensi, penurunan kemampuan untuk beraktivitas dan melemahnya indra pengecap dan pencium. Kekurangan selenium dapat mengakibatkan lemah otot, pengerasan pembuluh darah arteri dan otot jantung. Semua data ini memperlihatkan bahwa sewaktu Allah menciptakan manusia dari tanah liat, Dia menggabungkan zat-zat kandungannya dalam jumlah yang ideal. ${ }^{38}$

Di lain tempat, al-Quran memberitahu kita bahwa manusia diciptakan dari 189.

\footnotetext{
${ }^{37}$ Caner Taslaman, Miracle of the Quran, h.
}

${ }^{38}$ Ibid., h. 189. 
air, dan bahkan segala kehidupan berasal dari air. Allah berfirman:

Dan Dia (pula) yang menciptakan manusia dari air lalu Dia jadikan manusia itu (punya) keturunan dan $m u$ shaharah dan adalah Tuhanmu Maha Kuasa. (QS. al-Furqān [25]: 54).

Dan dari air Kami jadikan segala sesuatu yang hidup (QS. al-Anbiyā [21]: 30).

Berdasarkan ayat-ayat di atas, air adalah unsur biologis dasar bagi makhluk hidup. Sel terbentuk dari air dengan perbandingan yang bervariasi antara $60 \%$ sampai $80 \%$. Sel yang bahan dasarnya adalah air merupa-kan makhluk hidup. Tanpa air tidak akan ada kehidupan. Air terdiri dari dua atom hidrogen dan satu atom oksigen. Air, dengan unsur kimia pembangunnya telah diatur sempur-na, terbuat dari atom tanpa kehidupan organik dan 99\% ruang hampa. Bagaimana makhluk hidup dan hewan diciptakan dari sesuatu yang 99\%-nya merupakan ruang hampa? Bagaimana suatu entitas yang terbuat dari bahan anorganik dan tak bernyawa menjadi hidup?

Dialah Allah Yang Menciptakan, Yang Mengadakan, Yang Membentuk Rupa, Dia memiliki nama-nama yang indah. Apa yang di iangit dan di bumi bertasbih kepada-Nya. Dan Dialah Yang Mahaperkasa, Mahabijaksana (QS. al-Ḥasyr [59]: 24).

Kasus lain adalah ayat: "Dia menciptakan manusia dari 'alaq" (QS. al'Alaq [96]: 2). Para ulama menafsirkan arti kata 'alaq dengan al-dam al-jāmid (segumpal darah yang beku). Sedangkan dalam surah al-Mu'minun disebutkan proses kejadian manusia itu sebagai berikut:

Dan sesungguhnya Kami telah menciptakan manusia dari suatu saripati (berasal) dari tanah, kemudian Kami jadikan saripati itu air mani (yang disimpan) dalam tempat yang kokoh (rahim), kemudian air mani itu Kami jadikan segumpal darah, lalu segumpal darah itu Kami jadikan segumpal daging, dan segumpal daging itu Kami jadikan tulang belulang, lalu tulang belulang itu Kami bungkus dengan daging. kemudian Kami jadikan Dia makhluk yang (berbentuk) lain. Maka Maha sucilah Allah, Pencipta yang paling baik. (QS. al-Mu'minūn [23]: 12-14).

Dari ayat-ayat di atas jelaslah bahwa periode kedua dari kejadian manusia adalah al-'alaq setelah annutfah. Dari sini dapat disimpulkan bahwa proses kejadian manusia terdiri dari lima periode: (1) an-Nuṭah $\rightarrow$ (2) al-'Alaq $\rightarrow$ (3) al-Mudghah $\rightarrow$ (4) al'Izam $\rightarrow$ (5) al-Lahm.

Apabila seseorang mempelajari embriologi dan percaya akan kebenaran al-Quran, maka dia sulit menafsirkan kalimat al-'alaq tersebut dengan segumpal darah yang beku. Menurut embriologi, proses kejadian manusia terbagi dalam tiga periode:

Pertama, periode ovum. Periode ini dimulai dari fertilisasi (pembuahan) karena adanya pertemuan antara sel kelamin bapak (sperma) dengan sel ibu (ovum), yang kedua intinya bersatu dan membentuk struktur atau zat baru yang disebut zygote. Setelah fertilisasi berlangsung, zygote membelah menjadi dua, empat, delapan, enam belas sel, dan seterusnya. Selama pembelahan ini, 
zygote bergerak menuju ke kantong kehamilan, kemudian melekat dan akhirnya masuk ke dinding rahim. Peristiwa ini dikenal dengan nama implantasi.

Kedua, periode embrio. Periode ini adalah periode pembentukan organorgan. Terkadang organ tidak terbenuk dengan sempurna atau sama sekali tidak terbentuk, misalnya, jika hasil pembelahan zygote tidak bergantung atau berdempet pada dinding rahim. Ini dapat mengakibatkan keguguran atau kelahiran cacat bawaan.

Ketiga, periode foetus. Periode ini adalah periode perkembangan dan penyempurnaan dari organ-organ tadi, dengan perkembangan yang amat cepat dan berakhir pada waktu kelahiran. ${ }^{39}$

Quraish Shihab menjelaskan lebih lanjut, bahwa jika kita melihat pada QS. al-Mu'minun [23]: 12-14 di atas, periode kejadian manusia itu: periode pertama adalah (1) an-Nutfah $\rightarrow$ periode kedua adalah al-'Alaq $\rightarrow$ periode ketiga adalah al-Mudghah. Al-Mudghah-yang berarti sepotong daging-menurut al-Quran (QS. al-Hajj [22]: 5) terbagi dalam dua kemungkinan: al-mukhallaqah (sempurna kejadiannya) dan ghayru mukhallaqah (tidak sempurna kejadiannya). Dari sini, tambah Shihab, bila diadakan penyesuaian antara embriologi dengan al-Quran dalam proses kejadian manusia, nyata bahwa periode ketiga yang disebut al-Quran sebagai alMudghah me-rupakan periode kedua menurut embriologi (periode embrio). Dalam periode inilah terbentuknya organ-organ terpenting. Sedangkan periode keempat dan kelima menurut al-

${ }^{39}$ M. Quraish Shihab, “Membumikan” alQuran, h. 58.
Quran sama dengan periode ketiga (periode foetus). ${ }^{40}$

Dalam membicarakan al-'alaqyang oleh para mufasirin diartikan segumpal darah-didapati per-tentangan antara penafsiran tersebut dengan hasil penyelidikan ilmiah. Karena periode ovum terdiri atas ectoderm, endoterm dan rongga amnion, yang terdapat di dalamnya cairan amnion. Unsur-unsur tersebut tidak mengandung komponen darah. Dari titik tolak ini, tegas Shihab, mereka menolak penafsiran al-'alaq dengan segumpal darah, cair atau beku. Mereka berpendapat bahwa al-'alaq adalah sesuatu yang bergantung atau berdempet. Penafsiran ini sejalan dengan pengertian bahasa Arab, dan sesuai pula dengan embriologi yang dinamai implantasi. Bahasa Arab tidak menjadikan arti al-'alaq khusus untuk darah beku, tetapi salah satu dari artinya adalah bergantungan atau berdempetan. ${ }^{41}$

Caner Taslaman menambahkan, proses menempelnya embrio pada dinding rahim merupakan hasil suatu sistem yang rumit. Untuk menembus lapisan asam pada dinding jaringan rahim, embrio mengeluarkan enzim (hyaluronidase) yang mengubah jarringan rahim dan memungkinkan embrio menembusnya, dan kemudian menetap di sana seperti tumbuhan. Sejak itu, rahim menyediakan kebutuhannya akan makanan dan oksigen. Hyaluronidase yang di-keluarkan oleh embrio mempercepat penguraian asam hyaluronic. Lebih jauh lagi, embrio melepaskan se-jumlah zat kimia untuk mem-pertahankan diri dari sistem imun si ibu. Tanpa zat-zat

\footnotetext{
${ }^{40}$ Ibid., h. 59.

${ }^{41}$ Ibid., h. 59.
} 
itu, embrio akan diperlakukan sebagai zat asing yang harus dihancurkan. ${ }^{42}$

\section{Relasi al-Quran dan Sains}

Bertitik tolak dari uraian di atas, maka yang perlu dikemukakan selanjutnya adalah bagaimanakah sesungguhnya relasi al-Quran dan sains dari perspektif Ian Grame Barbour dengan fokus pada dua persoalan yang sudah diulas tersebut?

Merujuk pada empat tipologi hubungan sains dan agama yang dikemukakan oleh Barbour, yakni konflik, independensi, dialog, dan integrasi; maka dapat digambarkan hubungan alQuran dan sains sebagaimana diuraikan di bawah ini.

\section{Kasus I: Kejadian Alam Semesta}

Untuk kasus kejadian alam semesta, antara sains dan al-Quran dapat dilihat sebagai berkonflik di satu sisi, dan berintegrasi di sisi yang lain.

Jika merujuk pendapat Einstein dan Hubble, bahwa alam semesta ini dimulai dengan ledakan suatu benda raksasa, dari ledakan itu sampai kini telah berlangsung 500 juta tahun. Ada bintang-bintang baru yang muncul dan pula yang mati. Keadaan ini berlalu tanpa akhir, dan tatasurya kita bertahan untuk masa 500 juta tahun lagi, kemudian membesar lalu pecah dan menghilan. Kedua ilmuwan ini berkesimpulan bahwa semesta ini terwujud dengan sendirinya tanpa pencipta kuasa, dan bahwa semua benda angkasa itu terwujud secara alamiah menurut prosesnya dalam hukum evolusi. Sementara itu, manusia sebagaimana bintang datang dan pergi, lahir dan mati tanpa bekas dan resiko. Mereka

\footnotetext{
${ }^{42}$ Caner Taslaman, Miracle of the Quran, $\mathrm{h}$. 200.
}

berkesimpulan bahwa semesta raya ini masih bertumbuh. Tentu saja pendapat ini tidak bisa diterima oleh al-Quran. Karena Kitab Suci ini dengan tegas mengatakan bahwa alam semesta ini diciptakan oleh Tuhan dari ketiadaan, dan Dia terus-menerus mengawal dan mengurus ciptaan-Nya itu tanpa beristirahat sejenak pun.

Sesungguhnya ilmu Allah menjangkau segala sesuatu yang di langit dan yang di bumi. Dia Maha Mengetahui apa yang terlintas dalam hati. Dia Maha Mengetahui usaha segala makhluk, mengetahui apa yang di darat dan di laut, mengetahui daun-daun yang berguguran di malam gelap gulita dan lain sebagainya (baca: QS. al-An'am [6]: 3, 59; QS. Hud [11]: 5-6, dan QS. al-Mulk [67]: 13-14).

Sementara itu, sains dan al-Quran bisa berintegrasi. Sebagaimana dikatakan oleh Barbour, beberapa orang mengupayakan suatu integrasi yang lebih sistematik antara sains dan agama. Dengan berpijak pada agama, maka aspek-aspek sains dianggap sejalan dengan keyakinan agama.

Integrasi ini dideskripsikan oleh Barbour sebagai berikut: "orang lain berangkat dari tradisi keagamaan tertentu dan memperlihatkan bahwa banyak hal dari keyakinannya sejalan dengan ilmu pengetahuan modern, tetapi beberapa keyakinan harus dirumuskan kembali dalam terang sorotan teori-teori ilmiah khusus. Saya menyebutkan suatu pendekatan seperti itu teologi alam (theology of nature, di dalam satu tradisi keagamaan) daripada teologi natural (natural theology, yang ber-argumentasi dari ilmu pengetahuan saja). Beberapa versi dari teologi alam 
memakai suatu filsafat utuh-terpadu seperti filsafat proses, yang menguraikan secara sistematik serangkaian konsep yang ada sangkut pautnya, baik dengan ilmu pengetahuan maupun dengan agama. ${ }^{43}$

Sebagaimana dikatakan oleh Prof. Dr. M. Yusuf Musa, bahwa al-Quran tidak berlawanan atau bertentangan dengan ilmu, terutama ilmu alam dengan pengertian yang sejalan dengan ajaran akidah. Kelebihan Islam yang terbesar adalah bahwa ia membuka bagi umat Islam pintu-pintu ilmu pengetahuan seraya menghimbau mereka untuk masuk mencari dan mengembangkan ilmu itu. Bukanlah kelebihannya dalam membuat mereka malas mencari ilmu dan melarang mereka memperluas penelitian dan penalaran karena semata-mata mereka menyangka bahwa mereka telah memiliki semua jenis ilmu. Umat Islam dihimbau oleh al-Quran untuk maju dalam kehidupan dengan mempelajari pelbagai ilmu pengetahuan sesuai dengan kedudukannya sebagai khalīfah Allah di bumi ini. ${ }^{44}$

Dalam tataran yang lebih dalam lagi, maka seorang ilmuwan Muslim akan semakin dekat kepada ciptaan Allah ketika ia menemukan fe-nomenafenomena alam yang menakjubkan. Sebab, ia sadar bahwa aneka fenomena alam tidaklah berdiri sendiri, mereka saling terkait satu sama lain. Fenomena alam tidak muncul sia-sia tanpa pesan, tanpa tujuan. Ilmuwan Muslim, tulis Agus Purwanto, mencoba memahami dan menangkap pesan yang terkandung

\footnotetext{
${ }^{43}$ Ian G. Barbour, Menemukan Tuhan, h. 32-33. 70.
}

di balik aneka fenomena alam. Mengamati dan merenungkan alam berarti memahami kebijakan-Nya, ketika misteri dari sebuah fenomena alam tersibak, ilmuwan Muslim secara spontan akan menyucikan Sang Pengendali yang tersembunyi di balik fenomena tersebut. Tidak sekadar bertasbih, melainkan juga memohon agar upaya menyingkap tabir alam dan hasilnya tidak menggelincirkan serta menyeretnya ke dalam azab-Nya dengan berzikir: "Ya Tuhan kami, tidaklah Engkau menciptakan semua ini sia-sia. Maha Suci Engkau dan hindarkanlah kami dari azab api neraka." 45

\section{Kasus II: Evolusi dan Penciptaan Manusia}

Hubungan al-Quran dan teori evolusi Darwin tampaknya tidak bisa dikompromikan, karena keduanya tidak mungkin bertemu. Meskipun, sebagaimana diuraikan di atas, ada beberapa ilmuwan Muslim yang mengikuti teori ini. Karena itu, jalan terbaik untuk kasus ini independensi. Sebagaimana ditulis oleh Barbour, konflik dapat dihindari kalau ilmu pengetahuan dan agama tetap berada dalam ruang-ruang hidup manusia yang terpisah. Ilmu pengetahuan dan agama berurusan dengan ranah-ranah yang berbeda dan aspekaspek realitas yang berbeda. Ilmu pengetahuan bertanya tentang bagaimana sesuatu bekerja dan mengandalkan data publik yang obyektif. Agama bertanya tentang nilai-nilai dan kerangka makna yang lebih besar bagi hidup pribadi. Dalam pandangan ini, dua bentuk wacana tidaklah bersaingan karena mereka melayani fungsi-fungsi

\footnotetext{
${ }^{45}$ Agus Purwanto, Nalar Ayat-ayat Semesta, h. 160.
} 
yang benar-benar berbeda. Dua jenis penyelidikan itu menawarkan pandangan-pandangan yang saling melengkapi tentang dunia, panda-ngan-pandangan yan tidak saling menyingkirkan satu sama lain. Pemisahan ruang (kompartementalisasi) semacam ini memang menghindarkan konflik, tetapi dengan risiko mencegah terbangunnya interaksi yang kon-struktif. ${ }^{46}$

\section{Sikap al-Quran Terhadap Evolusi Darwin}

Sementara itu, untuk hal yang berkaitan dengan asal-usul manusia, alQuran dan sains berhubungan integratif. Artinya, sains dapat memberikan penjelasan ilmiah mengenai proses kejadian manusia. Walaupun sekilas ayat-ayat al-Quran memberi informasi sederhana, namun sesungguhnya ia menggugah manusia untuk terus menyelam ke dalam samudra yang terkandung di dalamnya. Dan ini adalah pekerjaan para ilmuwan.

E. Penutup

Setelah penulis menguraikan panjang lebar di atas, maka diambil kesimpulan sebagai berikut:

1) Dalam mengemukan hubungan antara agama dan sains, Ian G. Barbour membagi ke dalam empat tipologi (konflik, independen, integrasi, dan dialog). Ia melihat bahwa keempat tipologi ini dijumpai di kalangan saintis dan agamawan.

2) Berkaitan dengan ayat-ayat al-Quran yang senada dengan pemikiran Ian G. Barbour memang ditemukan adanya kemungkinan sains menjelaskan ayat-ayat ilmiah dalam al-Quran.

\footnotetext{
31-32.
}

\footnotetext{
${ }^{46}$ Ian G. Barbour, Menemukan Tuhan, h.
}

3) Dengan perspektif Ian G. Barbour, ditemukan fakta bahwa relasi alQuran dan sains berada pada tipologi konflik, independen, dan integratif. Konflik terjadi ketika sains berbicara tentang alam yang terbebas dari campur tangan Tuhan; independensi terjadi ketika berkaitan dengan teori evolusi Darwin. Namun, integrasi terjadi juga ketika sains mampu memecahkan informasi-informasi ilmiah yang disajikan al-Quran.[]

\section{Daftar Pustaka}

Ali, Abdullah Yusuf, Qur'an: Terjemahan dan Tafsirnya, terj. Ali Audah, Jakarta: Pustaka Firdaus, 1994.

Ali, Maulana Muhammad, The Holy Qur'an: Arabic Text, English Translation, and Commentary, Lahore, Inc. U.S.A.: Ahmadiyah Anjuman Isha'at Islam, 1991.

Azra, Azyumardi, "Sambutan Rektor," Prospektus UIN Syarif Hidayatullah Jakarta "Wawasan 2010" Leading Toward Research University, Jakarta: UIN Jakarta Press, 2006.

Bagir, Zaenal Abidin, "Pengantar" dalam Ian G. Barbour, Juru Bicara Tuhan, Antara Sans dan Agama, terj. E.R. Muhammad, Bandung: Mizan, 2002.

Barbour, Ian G., Menemukan Tuhan dalam Sains Kontemporer dan Agama, terj. Fransiskus Borgias M, Bandung: Mizan, 2005.

Drees, Willem B., Religion and Science in Context: A Guide to the Debates, London dan New York: Routledge, 2010.

Mahzar, Armahedi, Revolusi Integralisme Islam: Merumuskan Paradigma 
Sains dan Teknologi Islami, Bandung: Mizan, 2004.

Musa, M. Yusuf, Al-Quran dan Filsafat, Jakarta: Bulan Bintang, 1988.

Purwanto, Agus, Ayat-ayat Semesta: Sisisisi al-Quran yang Terlupakan, Bandung: Mizan, 2013.

Purwanto, Agus, Nalar Ayat-ayat Semesta: Menjadikan al-Quran sebagai Basis Konstruksi Ilmu Pengetahuan, Bandung: Mizan, 2012.

Shihab, M. Quraish, "Membumikan” alQuran: Fungsi dan Peran Wahyu dalam Kehidupan Masyarakat, Bandung: Mizan, 1996.

Shihab, M. Quraish, Mukjizat al-Quran ditinjau dari Aspek Kebahasaan, Isyarat Ilmiah, dan Pemberitaan Gaib, Bandung: Mizan, 1997.

Shihab, M. Quraish, Tafsir al-Mishbāh: Pesan, Kesan dan Keserasian alQur'an, Vol. IV, Jakarta: Lentera Hati, 2001.

Syamsu, Nazwar, al-Qur'an Dasar Tanya Jawab Ilmiah, Jakarta: Ghalia Indonesia, t.th.

Syamsuddin, Ach. Maimun, Integrasi Mutlidimensi Agama dan Sains: Analisis Sains Islam al-Attas dan Mehdi Golshani, Yogyakarta: IRCiSoD, 2012.

Taslaman, Caner, Miracle of the Quran: Keajaiban al-Quran Mengungkap Penemuan-penemuan Ilmiah Modern, Bandung: Mizan, 2010.

Temple, Frederick, The Relations between Religion and Science: Eight Lectures Preached before the University of Oxford in the Year 1884 on the Foundation of the Late Rev. John Bampton, M.A,
Cambridge: Cambridge University Press, 2009.

Waston, "Hubungan Sains dan Agama: Refleksi Filosofis atas Pemikiran Ian G. Barbour", PROFETIKA: Jurnal Studi Islam, Vol. 15, No. 1, Juni 2014.

Zubaidi, Dialog antara Sains menurut Ian G. Barbour dengan Ayat-ayat alQur'an, Skripsi pada Fakultas Ushuluddin IAIN Walisongo Semarang, 2005. 